\title{
New records confirming the occurrence of the ghost shrimps Biffarius biformis \\ (Biffar, 1970) and B. fragilis (Biffar, 1971) (Decapoda, Callianassidae) in Brazil and the southwestern Atlantic
}

\author{
Mônica Lúcia Botter-Carvalho ${ }^{1,4}$, Paulo Vladmir Van Den Berg da Costa Carvalho² \& \\ Paulo Jorge Parreira dos Santos ${ }^{3}$ \\ ${ }^{1}$ Departamento de Biologia, Área de Ecologia, Universidade Federal Rural de Pernambuco-UFRPE, \\ Rua Dom Manoel de Medeiros, s/n, Dois Irmãos, CEP 52171-900, Recife, PE, Brasil \\ ${ }^{2}$ Petrobras Transportes S/A - TRANSPETRO, Rua Antônio Lumack Monte, 96, $4^{\circ}$ andar, \\ CEP 51020-905, Recife, PE, Brasil \\ ${ }^{3}$ Departamento de Zoologia, Centro de Ciências Biológicas, Universidade Federal de Pernambuco - UFPE, \\ Av. Professor Moraes Rego, Cidade Universitária, CEP 50670-420, Recife, PE, Brasil \\ ${ }^{4}$ Corresponding author: Mônica Lúcia Botter-Carvalho,e-mail: monica.botter@db.ufrpe.br; \\ monicabotter@yahoo.com.br
}

BOTTER-CARVALHO, M.L., CARVALHO, P.V.V.D.B.C. \& SANTOS, P.J.P. New records confirming the occurrence of the ghost shrimps Biffarius biformis (Biffar, 1970) and B. fragilis (Biffar, 1971) (Decapoda, Callianassidae) in Brazil and the southwestern Atlantic. Biota Neotrop. 12(3): http://www.biotaneotropica. org.br/v12n3/en/abstract?article+bn02012032012

Abstract: Previous records of the callianassid ghost shrimps Biffarius biformis (Biffar, 1971) and Biffarius fragilis (Biffar, 1970) from Pernambuco, northeastern Brazil, were considered as doubtful, because their original record (Carvalho et al. 1997) in a conference abstract cannot be considered as a valid publication. The original material examined by Carvalho et al. (1997) combined with the more recently collected material of $B$. biformis and $B$. fragilis, confirm the presence of these two species in Brazil and the southwestern Atlantic. Taxonomic and ecological remarks, as well as illustrations, are provided for both species.

Keywords: Callianassidae, Biffarius, new records, Brazil, Atlantic Ocean.

BOTTER-CARVALHO, M.L., CARVALHO, P.V.V.D.B.C. \& SANTOS, P.J.P. Novos registros confirmam a ocorrência dos camarões fantasma Biffarius biformis (Biffar, 1970) e B. fragilis (Biffar, 1971) (Decapoda, Callianassidae) no Brasil e sudoeste do Atlântico. Biota Neotrop. 12(3): http://www.biotaneotropica.org.br/ v12n3/pt/abstract?article+bn02012032012

Resumo: A ocorrência dos camarões fantasma Biffarius biformis (Biffar 1971) e Biffarius fragilis (Biffar 1970) no nordeste do Brasil têm sido considerada duvidosa, porque o registro original (Carvalho et al. 1997) realizado em resumo durante uma conferência regional não pode ser considerado válido. Neste trabalho, o estudo dos espécimens examinados por Carvalho et al. (1997), combinados com o material coletado mais recentemente, confirma a presença dessas duas espécies na costa brasileira e no sudoeste do Atlântico. São fornecidas novas informações taxonômicas, ecológicas e ilustrações.

Palavras-chave: Callianassidae, Biffarius, novos registros, Brasil, Oceano Atlântico. 


\section{Introduction}

Ghost-shrimps of the family Callianassidae (Axiidea) are among the most common burrowing crustaceans in coastal soft-bottom environments, with about $54 \%$ of all known species found in very shallow waters (0-2 m) (Dworschak 2004). About 155 callianassid species are known worldwide, 39 of them in the western Atlantic (Dworschak 2000); the majority of species are distributed in the Indo-West Pacific (Sakai 1999b, Dworschak 2000).

Seventeen species of callianassids have been reported for Brazil (Rodrigues 1971, Coelho \& Ramos-Porto 1986, Manning \& Felder 1991, Rodrigues \& Manning 1992a, b, Manning \& Lemaitre 1993, Botter-Carvalho et al. 1995, Coelho 1997, Melo 1999, Coelho et al. 2007). However, the actual species richness of these cryptic bioturbators may be heavily underestimated, which is partly due to sampling difficulties (see Garcia et al. 2003).

The genus Biffarius Manning and Felder, 1991 includes 11 smallsized species worldwide (Sakai 1999b, Tudge et al. 2000, Guzmán \& Thatje 2003, Poore 2008), three in the Atlantic Ocean and eight in the Pacific Ocean. At present, three species of this genus are known from Brazil: Biffarius delicatulus Rodrigues \& Manning, 1992, originally described from the coasts of São Paulo, and B. biformis (Biffar, 1971b) and B. fragilis (Biffar, 1970), both briefly reported from Pernambuco (Carvalho et al. 1997). However, only the description of $B$. delicatulus may be accepted as a valid record of Biffarius in Brazil. The records of the two northeastern congeners appeared in abstracts of a local conference (Carvalho et al. 1997), which was later merely cited by Coelho (1997) in his revision of the "Thalassinidea" (now Axiidea + Gebiidea). Coelho (1997) clearly stated that did not examine any specimens of B. biformis and B. fragilis. Melo (1999), in his major treatment of Anomura and "Thalassinidea", also referred to Carvalho et al. (1997) as being the first record of these two species in Brazil. More recently, Coelho et al. (2007) included B. biformis and $B$. fragilis in their checklist of Brazilian decapod crustaceans, based on the same earlier listing in Coelho (1997). Applying Article 9 of the International Code of Zoological Nomenclature (1999) the original record of B. biformis and B. fragilis (Carvalho et al. 1997) is not a published study, making the Brazilian records of these two species doubtful.

The present study is the first formal confirmation of the presence of B. biformis and B. fragilis in Brazil and the southwestern Atlantic, based on the material originally examined by Carvalho et al. (1997), as well as more recently (2003) collected material. The Brazilian material is illustrated and some taxonomic and ecological notes are provided.

\section{Materials and Methods}

All specimens of Biffarius biformis and B. fragilis were collected in the intertidal habitats of Pernambuco, northeastern Brazil (Figure 1). The northern sampling site (Site $1-7^{\circ} 48^{\prime} 44^{\prime \prime} \mathrm{S}$ and $34^{\circ}$ 48 ' $48^{\prime \prime} \mathrm{W}$ ) is located at Itamaracá Island next to the mouth of Santa Cruz Channel, which connects a large estuarine complex composed of several small rivers (Figure 1). At this site, the ghost shrimps were collected in the intertidal zone of a sandy beach (Praia do Forte Orange). The superficial layer of sediment consists of well-sorted coarse sand and the depth of the redox potential discontinuity layer is approximately $10 \mathrm{~cm}$. The anoxic layer consists of fine sand and mud sediments with abundant biogenic detritus. Salinity range during low tide is 31.0-34.5\%. The southern sampling sites (Site 2 and 3 ) are located in a southern area of Praia da Casa Caiada ( $7^{\circ} 59^{\prime} 42^{\prime \prime} \mathrm{S}, 34^{\circ}$ 49' $48^{\prime \prime} \mathrm{W}$ and $7^{\circ} 58^{\prime} 15^{\prime \prime} \mathrm{S}$ and $34^{\circ} 49^{\prime} 49^{\prime \prime} \mathrm{W}$, respectively), an urban beach polluted by domestic sewage (Figure 1). The beach is semienclosed by a groyne and a series of seven seawalls, which favour the deposition of fine sediments and increased water temperature and salinity mainly during summer (Pereira et al. 1996). Site 2 is located approximately $100 \mathrm{~m}$ outward from the shoreline, and is characterized by a depositional environment formed by an inshore gravel bank adjacent to the seawall. Site 3 is located in the intertidal zone of Praia da Casa Caiada (Figure 1). The sediment (muddy sand) here is poorly oxygenated, superficially covered by conspicuous microphytobenthic patches, and has a dense population of the snail Neritina virginea (L.). Pereira et al. (1996) reported the range of salinity and water temperature of $36.3-30.0 \%$ and $31.3-28.0{ }^{\circ} \mathrm{C}$ during summer and winter, respectively. Site 2 is characterized by moderate to poorly sorted quartz sand and 95\% biogenic debris (Pereira et al. 1996); the sub-surface layer is characterized by well-sorted fine sand.

Sampling took place during low tide, in the intertidal zone, using a bait suction ("yabby") pump, modified from that of Hailstone \& Stephenson (1961). The pumped water (with sediments) was sieved through a $0.3 \mathrm{~mm}$ mesh to retain callianassids and other gallery-associated infauna. All samples were fixed in $4 \%$ buffered seawater-formaldehyde solution and 24 hours later transferred into $70 \%$ ethanol. Biometric measurements were made using a digital caliper $(0.1 \mathrm{~mm})$ or a micrometric eyepiece, following Biffar (1971a) for morphometric standards. Drawings were made with the aid of a stereomicroscope equipped with a camera lucida.

At site 1, the density of ghost shrimp burrows was estimated as the mean number of burrow openings per $\mathrm{m}^{2}$ along five transects. At sites 2 and 3, this estimation was not possible due to co-occurrence of other infaunal, burrowing organisms, such as polychaetes and stomatopods.

The following abbreviations are used in the text: CL, carapace length (mm); TL, total length (mm); MZUSP, Museu de Zoologia da Universidade de São Paulo.

\section{Taxonomic Section}

\section{Biffarius biformis (Biffar, 1971b)}

Callianassa biformis Biffar 1971b: 225, Figure 1. - Rabalais et al. 1981: 101 .

\section{Biffarius biformis - Manning \& Felder 1991: 769.}

Material examined: Brazil, Pernambuco: Itamaracá Island, Praia do Forte Orange, Site 1, 1 đ̊ (4.17 mm CL), 23.XI.1995 (MZUSP 19074); Itamaracá Island, Praia do Forte Orange, Site 1, 1 ovigerous $\bigcirc$ (5.20 mm CL, $24.1 \mathrm{~mm} \mathrm{TL}), 23 . X I .1995$ (MZUSP 19072); Olinda, Praia da Casa Caiada, Site 2, 1 ( $4.73 \mathrm{~mm} \mathrm{CL}$ ), 23.XII.2003 (MZUSP 19073).

Ecology: Biffarius biformis was collected in the lower intertidal only. Burrow openings were very sparse $\left(<0.1 . \mathrm{m}^{-2}\right)$, small $(1-2 \mathrm{~mm}$ diameter) and rather inconspicuous, without mound-like accumulation of sediments. No commensals were observed in sieved sediments. The lower intertidal was largely dominated by the callianassid Neocallichirus maryae Karasawa, 2004, with some specimens of Callichirus major (Say 1818), and, in muddy patches near the lowtide level, Sergio guassutinga (Rodrigues 1971). Galleries of these ghost shrimps were inhabited by the pinnotherid crabs Austinixa aidae (Righi 1967) and Pinnixa sp.; small reddish polyclads were found only in galleries of $S$. guassutinga.

Biffarius biformis was previously recorded from both intertidal and subtidal habitats, burrowing in fine sand or mud bottoms (Biffar 1971b, Dörges 1972, Holland \& Polgar 1976, Rabalais et al. 1981, Prezant et al. 2002). Rabalais et al. (1981) stated that B. biformis is 


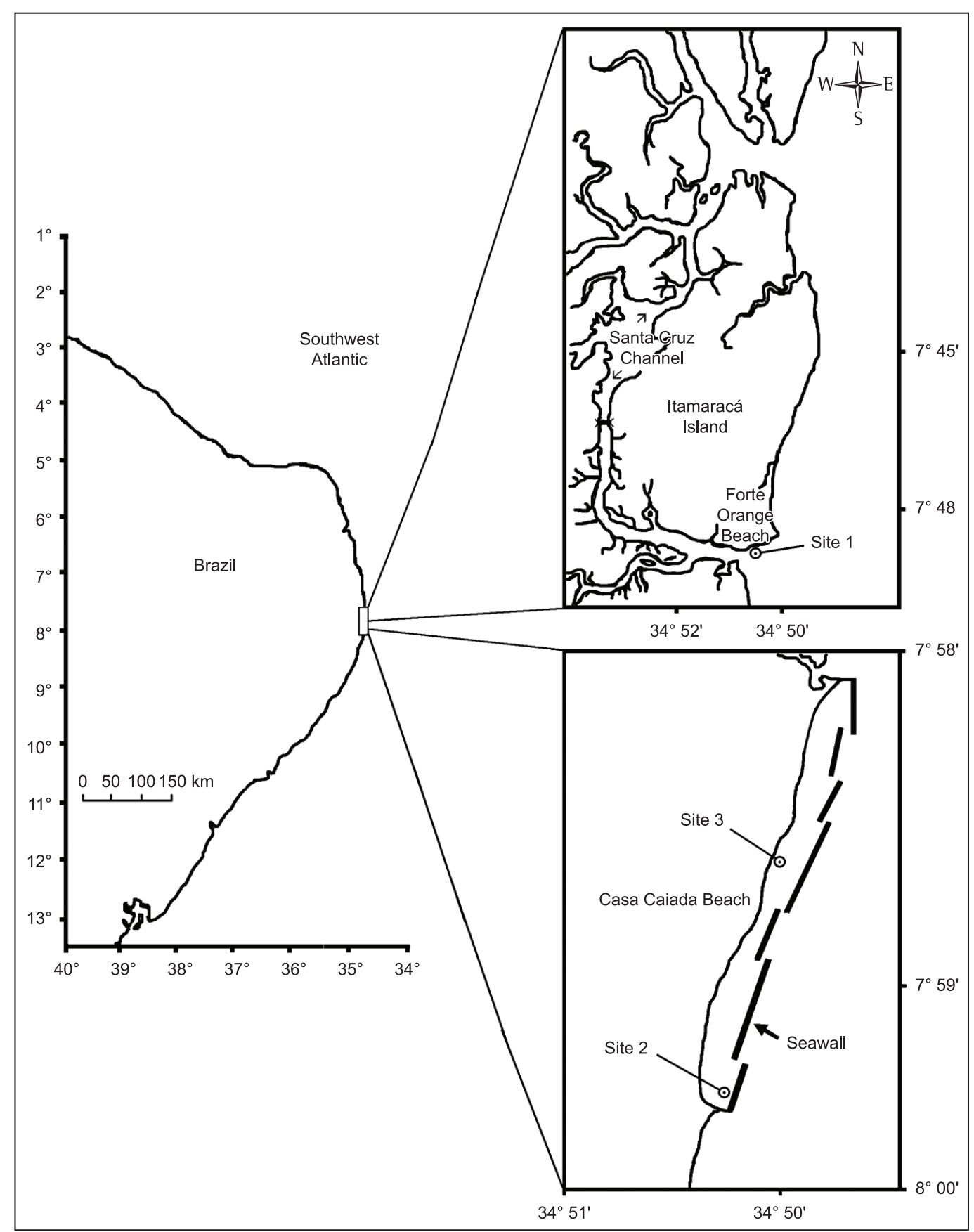

Figure 1. Map of the northeastern Brazilian coast showing localities of sampling sites.

the second most abundant "thalassinidean" on the outer continental shelf in the northwestern Gulf of Mexico (off southern Texas).

Distribution: Western Atlantic. USA: Atlantic coast from Massachusetts to Florida and Gulf of Mexico coast from Florida to Texas (Biffar 1971a, Rabalais et al. 1981, Williams 1984, Prezant et al. 2002, Heard et al. 2007); Brazil: Pernambuco (present study).

Remarks: The Brazilian specimens agree with the majority of the diagnostic features of B. biformis (as Callianassa biformis) given by Biffar (1971b). The major cheliped of Brazilian male individuals resembles the "strong" cheliped described by Biffar (1971b), differing from it only in the absence of fine elongate setae on the dorsal and ventral margins of the ischium and ventral margins of the merus, carpus and palm (Figure 2). On the other hand, the median spine on the telson mentioned as a diagnostic feature of B. biformis by Sakai (1999b), was not observed in the Brazilian material, which agrees with the description of Biffar (1971b). The paired lateral spiniform setae at each posterolateral corner of the telson described in the holotype by Biffar (1971b) are rather inconspicuous in the Brazilian material. Finally, in the Brazilian specimens, the distal margin of the telson is straight (Figure 2), whereas in the holotype of B. biformis, it was illustrated as slightly convex (Biffar 1971b). Generally, the tail fan of the Brazilian specimens matches more the drawing of individuals from the western Gulf of Mexico (Texas) provided by Rabalais et al. (1981). 
Rodrigues \& Manning (1992a) compared the main diagnostic features of $B$. biformis and B. delicatulus from southeastern Brazil and concluded that the two species are morphologically very close. However, the specimens examined here and identified as B. biformis clearly differ from $B$. delicatulus, for instance, in the armed ischium of the larger male cheliped, the eyestalks bearing a small rounded denticle on the dorsomesial surface, and the lateral margins of the telson being convergent and approximately of the same length as the uropodal endopod (Figure 2).

\section{Biffarius fragilis (Biffar, 1970)}

Callianassa fragilis Biffar 1970: 45, Figure 3 - Biffar 1971b: 667.

Callianassa fragilis - Sakai 1999b: 27.

Biffarius fragilis - Manning \& Felder 1991: 769. - Tudge et al. 2000: 133.

Biffarius cf. fragilis - Heard et al. 2007: 21.

Material examined: Brazil, Pernambuco: Itamaracá Island, Praia do Forte Orange, Site 1, 1 (6.91 mm CL), 23.XII.1995 (MZUSP 19068); Olinda, Praia da Casa Caiada, Site 2, 1 ovigerous +
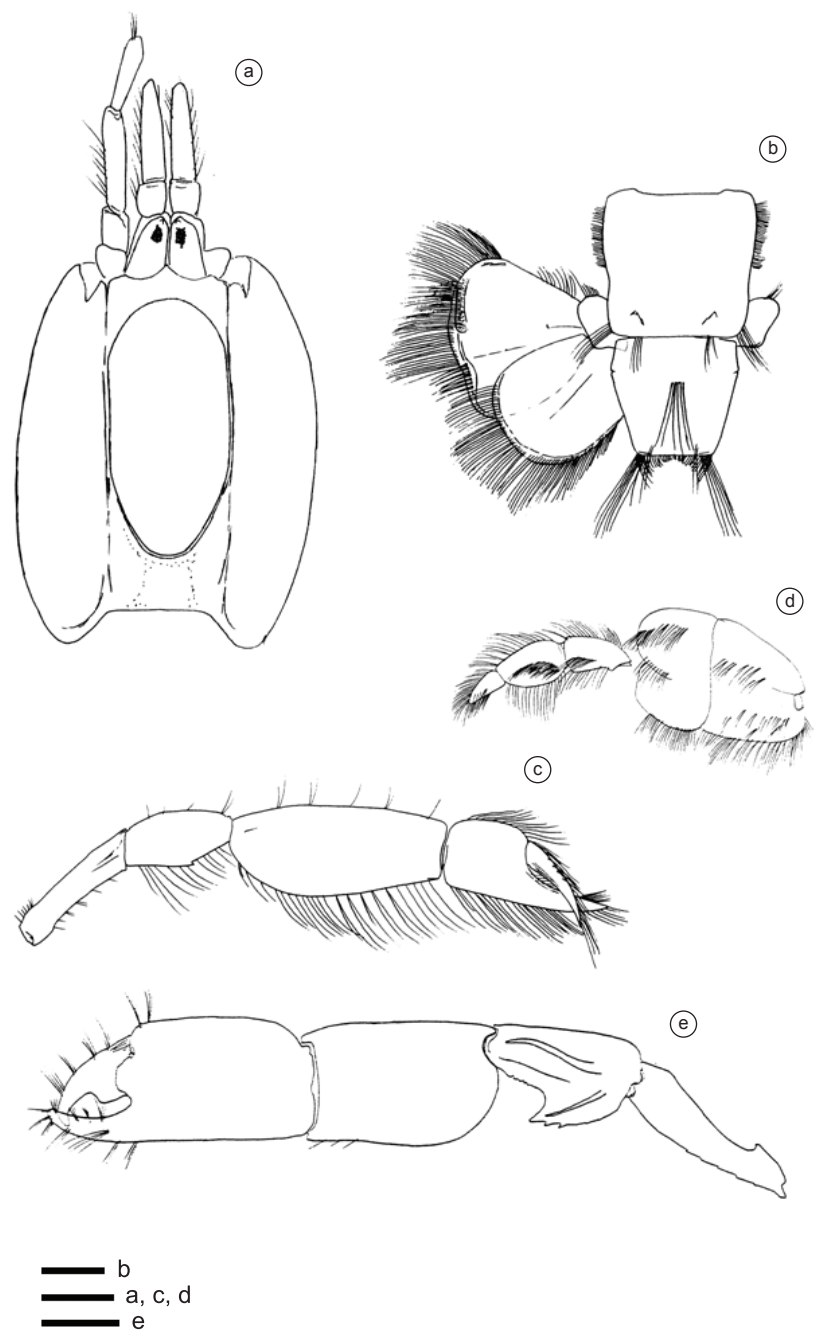

Figure 2. Biffarius biformis (Biffar, 1971): a) carapace and anterior appendages (dorsal view); b) sixth abdominal somite, telson and uropods (dorsal view); c) male minor cheliped (mesial view); d) third maxilliped (mesial view); e) male major cheliped (lateral view). Scale bars $=1 \mathrm{~mm}$.
(4.95 mm CL), 06.III.1996 (MZUSP 19069); Itamaracá Island, Praia do Forte Orange, Site 1, 1 đ̄ (5.08 mm CL, 23.5 mm TL), 22.III.1996 (MZUSP 19066); Itamaracá Island, Praia do Forte Orange, Site 1, 1 $\widehat{\jmath}$ (4.29 mm CL), 21.IV.1999 (MZUSP 19067); Olinda, Praia da Casa Caiada, Site 3, 1 ð̋ (4.91 mm CL), 23.XII. 2003. (MZUSP 19071); Olinda, Praia da Casa Caiada, Site 3, 1 ovigerous ${ }_{+}$(3.52 mm CL), 23.XII.2003 (MZUSP 19070).

Ecology: At all sampling sites, burrow openings of B. fragilis were very scarce, small ( $\sim 1 \mathrm{~mm}$ in diameter), and without mounds. At Site 3, the sympatric fauna included callianassids Neocallichirus maryae, Callichirus major and Lepidophthalmus siriboia Felder and Rodrigues, 1993. As for the previous species, no commensals were observed in galleries of B. biformis. Elsewhere, B. fragilis was also collected mainly on near-shore sandy habitats (Biffar 1971a, Manning \& Felder 1991).

Distribution. Western Atlantic. Southern Florida; Caribbean Sea: Puerto Rico, Antigua, Venezuela (Biffar 1970, 1971b; Manning \& Felder 1991); Brazil: Pernambuco (present study). Eastern Pacific. Galapagos and Costa Rica (Biffar 1972; Vargas \& Cortes 1999) [eastern Pacific records require both morphological and genetic confirmation].

Remarks: The Brazilian material of $B$. fragilis generally agrees with the descriptions of $B$. fragilis (as Callianassa fragilis) in Biffar (1970, 1971a), except for some subtle differences. The Brazilian

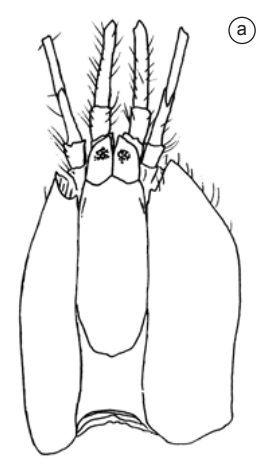

(a)
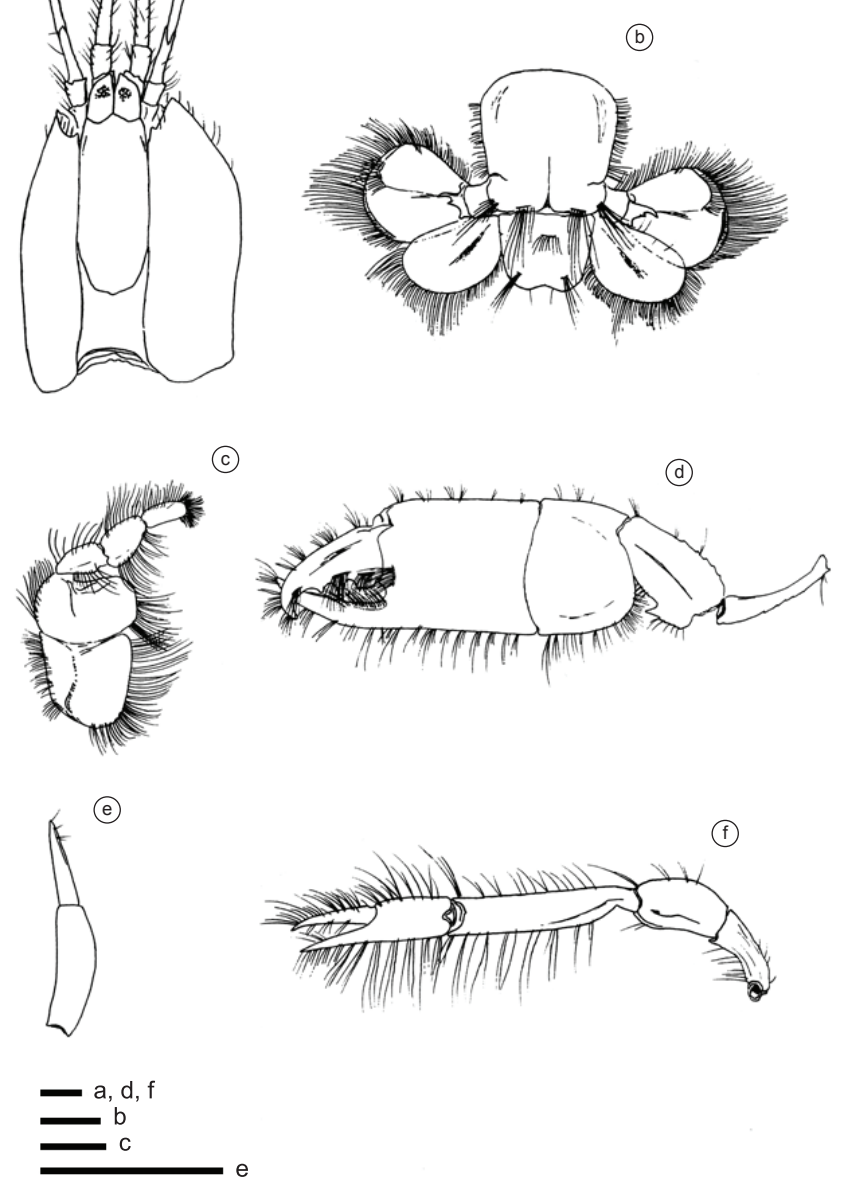

Figure 3. Biffarius fragilis (Biffar, 1970): a) carapace and anterior appendages (dorsal view); b) sixth abdominal somite, telson and uropods (dorsal view); c) third maxilliped (mesial view); d) male major cheliped (lateral view); e) male first pleopod; f) male minor cheliped (mesial view). Scale bars $=1 \mathrm{~mm}$. 


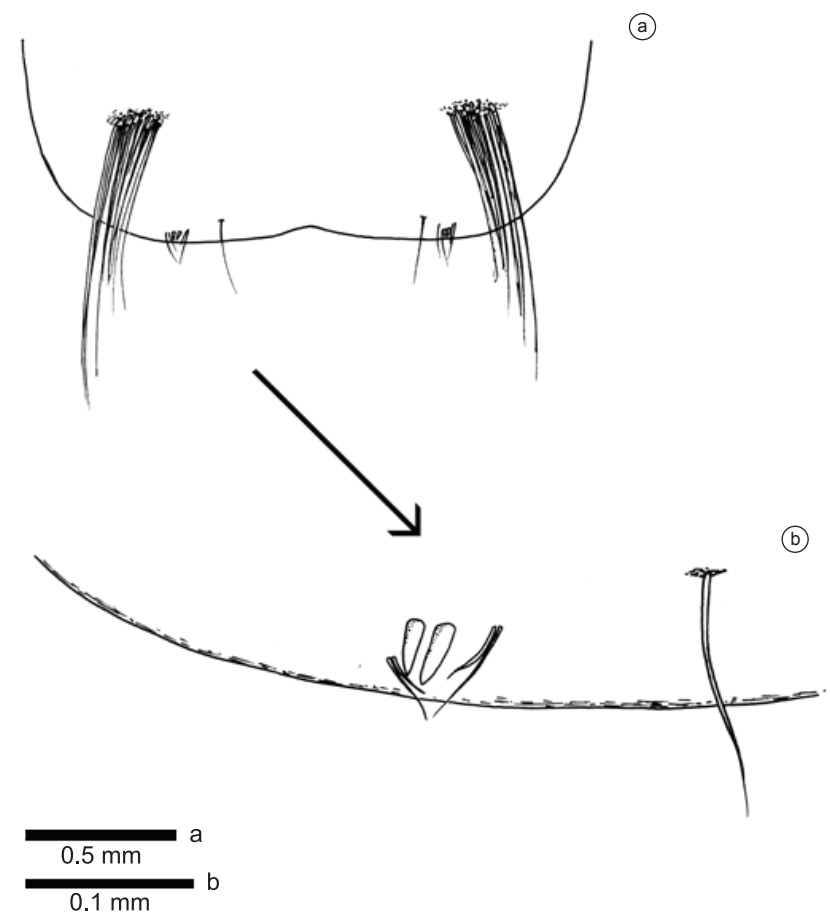

Figure 4. Biffarius fragilis (Biffar, 1970): a) posterior margin of telson; b) detail of spiniform setae near posterior margin.

specimens have 4-6 serrations on the ventral "hook" of the merus of the male major cheliped, as opposed to 3-4 as described by Biffar (1971a); the ventral margin itself has 10-13 denticles compared to the consistent 11 observed by Biffar (1971a). In the present material, the ischium of the third maxilliped bears 16-19 weak denticles on the mesial surface, whereas Biffar (1971a) observed 16-18 denticles. A pair of small spiniform setae on each posterolateral corner of the telson was observed in the Pernambuco material (Figure 4), but not mentioned or illustrated by Biffar (1970, 1971a). The Brazilian material partially agrees with the description in Heard et al. (2007), who mentioned the presence of only one spiniform setae in the material of $B$. fragilis from South Carolina. Therefore, our observations support the suggestion of Heard et al. (2007) that this character may be variable.

\section{Discussion}

The family Callianassidae has been revised first by Manning \& Felder (1991), and then by Sakai (1999b). Manning \& Felder (1991) erected the genus Biffarius for Callianassa biformis and C. fragilis, the former being its type species. Sakai (1999b, 2005) treated Biffarius along several other genera established by Manning \& Felder (1991) again under Callianassa Leach 1814. However, a preliminary phylogenetic analysis of the Callianassidae (Tudge et al. 2000), did not support Callianassa sensu lato = sensu Sakai (1999b). Callianassa was also recovered as possibly polyphyletic group in a recent DNA-based analysis (Robles et al. 2009). Therefore, in the present study, both species were retained in the genus Biffarius sensu Manning \& Felder (1991).

The present records from Pernambuco extend considerably the geographic ranges of B. biformis and B. fragilis from the Caribbean/ Florida region south to Brazil. These two species now have the widest north-south ranges among the species of Biffarius. Their apparent disjunctive distribution may be simply due to the paucity of sampling along the northern and eastern coast of Brazil.

\section{Acknowledgements}

The authors are extremely grateful to Drs. Arthur Anker and Patricio Hernáez for comments provided on an earlier version of the manuscript. The authors also thank Janet W. Reid for revision of the English.

\section{References}

BIFFAR, T.A. 1970. Three new species of Callianassidae shrimp (Decapoda, Thalassinidea) from the western Atlantic. Proc. Biol. Soc. Wash.83:35-49.

BIFFAR, T.A. 1971a. The genus Callianassa (Crustacea, Decapoda, Thalassinidea) in South Florida, with keys to the western Atlantic species. Bull. Mar. Sci. 21:637-715.

BIFFAR, T.A. 1971b. New species of Callianassa (Decapoda, Thalassinidea) from the western Atlantic. Crustaceana 21:225-236. http://dx.doi. org/10.1163/156854071X00562

BOTTER-CARVALHO, M.L., CARVALHO, P.V.V.C. \& RAMOS-PORTO, M. 1995. Registro de Neocallichirus rathbunae (Schmitt, 1935) em águas do litoral brasileiro (Decapoda: Callianassidae), Trab. Oceanogr. Univ. Fed. Pe. 23:199-202. [dated 1994/95, published 1995].

CARVALHO, P.V.V.C., BOTTER-CARVALHO, M.L. \& RAMOS-PORTO, M. 1997. Ocorrência de Biffarius biformis (Biffar, 1971) e B. fragilis (Biffar, 1970) (Crustacea, Decapoda, Callianassidae) no Atlântico Sul Ocidental: litoral de Pernambuco, Brasil. In 11 Encontro de Zoologia do Nordeste. Fortaleza, p.23.

COELHO, P.A. 1997. Revisão das espécies de Thalassinidea encontradas em Pernambuco, Brasil (Crustacea, Decapoda). Trab. Oceanogr. Univ. Fed. Pe. 25:137-16.

COELHO, P.A., ALMEIDA, A.O., BEZERRA, L.E.A. \& SOUZA-FILHO, J.F. 2007. An updated checklist of decapod crustaceans (infraorders Astacidea, Thalassinidea, Polychelida, Palinura, and Anomura) from the northern and northeastern Brazilian coast. Zootaxa. 1519:1-16.

COELHO, P.A. \& RAMOS-PORTO, M. 1986. Sinopse dos crustáceos decápodos brasileiros (Famílias Callianassidae, Callianideidae, Upogebiidae, Diogenidae). Trab. Oceanogr. Univ. Fed. Pe. 19:27-53.

DÖRGES, J. 1972. Georgia coastal region, Sapelo Island, U.S.A.: Sedimentology and biology. VII. Distribution and zonation of macrobenthic animals. Senckenb. Mar. 4:183-216.

DWORSCHAK, P.C. 2000. Global diversity in the Thalassinidea (Decapoda). J. Crust. Biol. 20:238-245.

DWORSCHAK, P.C. 2004. Biology of Mediterranean and Caribbean Thalassinidea (Decapoda). In Symposium on "Ecology of large bioturbators in tidal flats and shallow sublittoral sediments - from individual behavior to their role as ecosystem engineers" (A. Tamaki, ed.). Nagasaki University, Nagasaki, p.15-22.

GARCIA, K.E., EMBRY, S.J., GROSSBLAT, D., HOLBROOK, A.M., MCLAREN, W.M., REED, S.K., WILDEY, H.C. \& SHUSTER, S.M. 2003. A comparison of two methods for sampling the Gulf of California mud shrimps, Neotrypaea uncinata (Crustacea: Thalassinidea). J. Nat. Hist. 37:1847-1854. http://dx.doi.org/10.1080/00222930110120980

GUZMÁN, G.L. \& THATJE, S. 2003. Biffarius pacificus, a new species of the Callianassidae (Crustacea: Decapoda: Thalassinidea) from northern Chile. Sci. Mar. 67(3):293-298.

HAILSTONE, T.S. \& STEPHENSEN, W. 1961. The biology of Callianassa (Trypaea) australiensis Dana, 1852 (Crustacea, Thalassinidea). Pap. Qd. Univ. 12:259-285

HEARD, R.W., KING, R.A., KNOTT, D.M., THOMA, B.P. \& THORNTONDEVICTOR, S. 2007. A guide to the Thalassinidea (Crustacea: Malacostraca: Decapoda) of the South Atlantic Bight. 30p. NOAA Professional Paper NMFS 8.

HOLLAND, A.F. \& POLGAR, T.T. 1976. Seasonal changes in the structure of an intertidal community. Mar. Biol. 37:341-348. http://dx.doi. org/10.1007/BF00387489

INTERNATIONAL CODE OF ZOOLOGICAL NOMENCLATURE - ICZN. 1999. The International Trust for Zoological Nomenclature 1999. http:// www.iczn.org/iczn/index.jsp

MANNING, R 1987. Notes on western Atlantic Callianassidae (Crustacea: Decapoda: Thalassinidea). Proc. Biol. Soc. Wash. 100:883-889. 
Biffarius biformis (Biffar, 1970) and B. fragilis (Biffar, 1971) (Decapoda, Callianassidae) in Brazil and the southwestern Atlantic

MANNING, R. \& FELDER, D.L. 1991. Revision of the American Callianassidae (Crustacea: Decapoda: Thalassinidea). Proc. Biol. Soc. Wash. 104:764-792.

MANNING, R. \& LEMAITRE, R. 1993. Sergio a new genus of ghost shrimp from the Americas (Crustacea: Decapoda: Callianasidae). Nauplius 1:39-43.

MELO, G.A.S. 1999. Manual de identificação dos Crustacea Decapoda do litoral brasileiro: Anomura, Thalassinidea, Palinuridea, Astacidea. Editora Plêiade, São Paulo, 551p.

PEREIRA, L.C.C., COUTINHO, P.N., MACEDO, S.J. \& COSTA, R.A.M. 1996. Conseqüências ambientais causadas por obras de contenção ao avanço do mar nas Praias de Casa Caiada e Rio Doce-PE, Brasil.). Trab. Oceanogr. Univ. Fed. Pe. 24:19-37.

POORE, G.C.B. 2008. Thalassinidean shrimps (Crustacea: Decapoda) from north-western Australia, including five new species. Records of the Western Australian Museum Supplement 73:161-179.

PREZANT, R.S., TOLL, R.B., ROLLINS, H.B. \& CHAPMAN, E.J. 2002. Marine macroinvertebrate diversity of St. Catherines Island, Am. Mus. Novit. 3367, 31p. http://dx.doi.org/10.1206/0003-0082(2002)367\%3C0 001:MMDOSC\%3E2.0.CO;2

RABALAIS, N.N., HOLT, A.S. \& WARREN FLINT, R. 1981. Mud shrimps (Crustacea, Decapoda, Thalassinidea) of the northwestern Gulf of Mexico. Bull. Mar. Sci. 31:96-115.

ROBLES, R., TUDGE, C.C., DWORSCHAK, P.C., POORE, G.C.B. \& FELDER, D.L. 2009. Molecular phylogeny of the Thalassinidea based on nuclear and mitochondrial genes. In Decapod Crustacean Phylogenetics (J.W. Martin, K.A. Crandall \& D.L. Felder, eds.). CRC Press, Taylor \& Francis Group, Boca Raton, London, New York, v.18, p.309-326. Crustacean Issues. series ed.
RODRIGUES, S.A. 1971. Mud shrimps of the genus Callianassa Leach from the Brazilian coast (Crustacea, Decapoda). Arq. Zool. 20:191-223.

RODRIGUES, S.A. \& MANNING, R.B. 1992a. Two new callianassid shrimps from Brazil (Crustacea: Decapoda: Thalassinidea). Proc. Biol. Soc. Wash. 105:324-330.

RODRIGUES, S.A. \& MANNING, R.B. 1992b. Poti gaucho, a new genus and species of ghost shrimp from southern Brazil (Crustacea: Decapoda: Callianassidae). Bull. Mar. Sci. 51:9-13.

SAKAI, K. 1999b. Synopsis of the family Callianassidae, with keys to subfamilies, genera and species, and the description of the new taxa (Crustacea: Decapoda: Thalassinidea). Zool. Verh. 326:152.

SAKAI, K. 2004. Dr. Plant's collection of the families Callianassidae and Gourretiidae (Decapoda, Thalassinidea) from Madagascar, with the description of two new genera and one new species of the Gourretiidae Sakai, 1999 (new status) and two new species of the Callianassidae Dana, 1852. Crustaceana 77(5):553-601. http://dx.doi. org/10.1163/1568540041718019

SAKAI, K. 2005. Callianassoidea of the world (Decapoda, Thalassinidea). Crustaceana Monogr. 4:1-200.

TUDGE, C.C., POORE, G.C.B. \& LEMAITRE, R. 2000. Preliminary phylogenetic analysis of generic relationships within the Callianassidae and Ctenochelidae (Decapoda: Thalassinidea: Callianassoidea). J. Crust. Biol. 20:129-149.

VARGAS, R. \& CORTÉS, J. 1999. Biodiversidad marina de Costa Rica: Crustacea: Decapoda (Penaeoidea, Sergestoidea, Caridea, Astacidea, Thalassinidea, Palinura) del Pacífico. Rev. Biol. Trop. 47(4):887-911

WILLIAMS, A.B. 1984. Shrimps, lobster, and crabs of the Atlantic coast of the eastern United States, Maine to Florida. Smithsonian Institution Press, Washington, 550p. 